\title{
Do estrogen antagonists and anti-androgens prevent the COVID-19's pulmonary involvement?
}

Mehrdad Jalalian

Note: Dr. Mehrdad Jalalian is an editor of Electronic Physician, this paper has been reviewed by three experts

Type of article: Hypothesis and Idea

\begin{abstract}
Male and female hormones are upregolators of expression of Angiotensin-converting Enzyme 2 (ACE2) gene. This short article proposes a hypothesis about the potential effect of estrogen antagonists and anti-androgens in preventing pulmonary involvement in COVID-19 infection through their downregulatory effect on ACE2 expression.
\end{abstract}

Keywords: COVID-19, Prophylaxis, Coronavirus, ACE2, S-protein, Estrogen, Testosterone

\section{Abbreviations / Acronyms:}

ACE2: Angiotensin-converting Enzyme 2, COVID-19: Coronavirus Disease 2019

\section{The Idea:}

Children carry the virus very frequently; but the pulmonary involvement is rare in childhood $(1,2)$. Based on the facts that (i) estrogen and testosterone are the upregulators of ACE2 gene and ACE2 plays the main role in binding with the coronavirus's S-protein (3), and (ii) the sex hormones are absent in childhood, using estrogen antagonists (in female adult) and anti-androgens (in male adult) may prevent the lower respiratory tract involvement in patients in early stage of COVID-19 infection. Such medicine should exclusively be absorbed by epithelial cells in the lung to avoid the systemic side effects. Medical staff and people who are living with patients may also benefit from such medicine as a prophylactic agent. Since the sex hormones may be main actor in the almost 0 and 1 (binary) age distribution model of pulmonary involvement among children and adults, I highly recommend examining this hypothesis at the earliest time.

\section{Conflict of Interest:}

There is no conflict of interest to be declared.

\section{References:}

1) $\mathrm{Wu} \mathrm{Z1,} \mathrm{McGoogan} \mathrm{JM1.Characteristics} \mathrm{of} \mathrm{and} \mathrm{Important} \mathrm{Lessons} \mathrm{From} \mathrm{the} \mathrm{Coronavirus} \mathrm{Disease} 2019$ (COVID-19) Outbreak in China: Summary of a Report of 72314 Cases From the Chinese Center for Disease Control and Prevention. JAMA. 2020 Feb 24. DOI: 10.1001/jama.2020.2648. PMID: 32091533. [Epub ahead of print]

2) Cai J, Xu J, Lin D, Yang Z, Xu L, Qu Z, Zhang Y et al. A Case Series of children with 2019 novel coronavirus infection: clinical and epidemiological features. A Case Series of children with 2019 novel coronavirus infection: clinical and epidemiological features. Clin Infect Dis. 2020 Feb 28. DOI: 10.1093/cid/ciaa198. PMID: 32112072

3) Hussin A.RothanaSiddappa N.Byrareddy. The epidemiology and pathogenesis of coronavirus disease (COVID-19) outbreak. Journal of Autoimmunity. Available online 26 February 2020. DOI: 10.1016/j.jaut.2020.102433, In Press

\section{Corresponding author:}

Dr. Mehrdad Jalalian. Editor-in-Chief, Electronic Physician Journal, Mashhad, Iran.

Tel: +98.9164337176, E-mail: mehrdad.medic@gmail.com

Received: February 28, 2020, Accepted: March 14, 2020, Published: March 2020

(C) 2020 The Authors. This is an open access article under the terms of the Creative Commons Attribution-NonCommercialNoDerivs License, which permits use and distribution in any medium, provided the original work is properly cited, the use is non-commercial and no modifications or adaptations are made. 